\title{
40 years of the New York Convention
}

\author{
by Professor J E Adams
}

At a colloquium held to celebrate the 40th anniversary of the 1958 UN Convention on the Recognition and Enforcement of Foreign Arbitral Awards the influence of the Convention, its past and future were reviewed. The speakers' papers have now been published and are summarised here by Professor Adams of London University.

$\mathrm{O}$ the 40th anniversary of the United Nations Convention on the Recognition and Enforcement of Foreign Arbitral Awards (New York, 1958) a colloquium entitled 'New York Convention Day' was held on 10 June 1998 at United Nations HQ in New York to celebrate the occasion. The papers presented have now been published, under the rather uninspired title 'Enforcing Awards under the New York Convention - Experience and Prospects' (United Nations Publication, Sales No. E99V2, ISBN 9211336090 - available from the Stationery Office). They raise a number of significant issues.

\section{RETROSPECT}

The 50 pages cover the subject under five headings, in chronological order. After the welcome and opening address by the UN Secretary General, two of the 'founding fathers', Professor Pieter Saunders and Ottorindt Glossner, recount their personal recollections of the making of the convention. The former concentrates on the evolution of the proposal and its realisation, the latter focuses on the delegates. He pays a touching tribute to, amongst others, the late Neil Pearson, and how that delightful man would have enjoyed being described as ‘a legal practitioner of sorts'! (Perhaps V V 'Johnny' Veeder QC, a later speaker, might be a little a less pleased at being listed as 'Attorney, London'.)

\section{FUTURE PROSPECTS}

Following that wholly fitting opening, s. II contains three assessments of the convention's value. Robert Briner, chairman of the ICC Court of Arbitration, the 1953 initiator of the whole project, led off. He identifies possible areas for improvements of which the first is a need to deal with absence of machinery for efficient and universal enforcement procedure. He sees the suggested international court as a project for some time in the next century, and so concentrates on an agenda for the next decade. Present, and pressing, problems derive from globalisation and privatisation, which have increased the volume of disputes, and make both a numerical and geographical increase of qualified arbitrators imperative. The breakdown of national court systems also makes the continued growth of arbitration essential, accompanied by a reduction in court involvement in arbitral proceedings, possibly by shifting entirely to supervision by enforcing courts and not only by courts of the arbitral seat. More thought is needed for mediation and conciliation to supplement, and not supplant, arbitration in the international arena and for better ways to resolve small value disputes. His other suggestions foreshadow themes taken up by later papers.

\section{HOPE FOR GLOBALISATION?}

Fali S Nariman, President of ICCA, then deals with the convention's contribution to the globalisation of international commercial arbitration. He links it with the other products of the United Nations Commission on International Trade Law (UNCITRAL), the Arbitration Rules of 1976 and the Model Law on International Commercial Arbitration of 1985, and then addresses the issue of whether the convention can 'hope to achieve a greater globalisation of concepts and approaches'. Sadly, he thinks it unlikely due to the persistence of state sovereignty amongst the 117 signatory states. He details the failure of another UN Convention, that on Consular Relations of 1963, when a Paraguayan national was tried for and convicted of murders, having been denied access to consular advice. The American courts declined jurisdiction over the alleged breach of the convention, so on 3 April 1998 Paraguay invoked the jurisdiction of the ICJ, which on 9 April unanimously accepted the case and requested, in effect, a stay of execution pending its further hearing. A petition to stay execution was denied (6-3) in the US Supreme Court, as no law compelled enforcement of the ICJ's (unanimous) order, and the hapless Mr Breard was executed on 14 April. One can understand Dr Nariman's scepticism! He further develops the reasons for his pessimism, which accepting that those who drafted the convention had no realistic choice but to accept national court enforcement.

\section{BENEFITS OF MEMBERSHIP}

Finally in this section, $\mathrm{Sr}$ Cardenas, the Argentinian Ambassador, discusses the benefits of membership of the convention, significantly that of greater certainty in international commerce. The Latin American countries are late arrivals on the international abitral stage, so this display of enthusiasm is welcome. 


\section{CURRENT CONCERNS}

In the third section, the speakers turn to current concerns. These are identified under the following main areas.

\section{The need for writing}

Neil Kaplan, from Hong Kong, continues his examination of the art. II(2) requirement of writing, including the need for signature and exchange. These do 'not conform with international trade practices', Kaplan says, citing bills of lading, some brokers' notes and salvage agreements, 'the battle of the forms' and the concept of tacit acceptance. He cites various national statutes dealing with these problems and regrets the failure of the Model Law to address the issue. Can an award based on one of those definitions be enforced under the convention? This paper places the issue on the list of desirable reforms.

\section{Third parties}

M Jean-Louis Devolvé of Paris then tackles the problems of whether, when and how third parties can be bound by arbitration agreements, particularly acute when the original agreement incorporating the arbitration clause has been assigned so that a former third party may now find itself potentially a party to a dispute. The convention does not address the issue but, chiefly through the medium of art. V, aims to introduce safeguards which may serve to make the hesitant third party less reluctant to become involved in the arbitration. $M$ Devolvé however does not advocate amendment of the convention but instead urges national courts to give effect to transfer of contractual obligations, consistent with the applicable laws, to include the arbitration clause. orders for interim measures do not qualify for enforcement abroad, or such is the 'better view'. Arguments to the contrary will not solve the problem, and a supplementary convention is desirable; its drafting would not be difficult, given various criteria put forward. The present position is unsatisfactory for the transnational trader. Urgent reform is called for.

Professor Lebedev starts by stressing that only new solutions to fresh problems will preserve and further the established international standing and acceptance of arbitration as a dispute resolution mechanism. He identifies one pressing problem of interaction - 'mutual assistance' between courts and arbitrators. The International Law Association adopted a set of principles on Provisional and Protective Measures in International Litigation in 1996, and sent it to UNCITRAL and the Hague Conference of International Law for consideration (Mr Veeder also mentions this aspect). That work could well provide a valuable aid for dealing with urgent needs of arbitral proceedings. National laws or arbitration rules moreover may be restricted to assets 'the subject matter of the dispute', and arbitral orders do not bind banks or other relevant third parties. In some jurisdictions, the courts will not make interim measures once an arbitration is afoot (witness well-known problems over injunctions in the USA). The professor, too, favours appropriate reform, by a new convention or addition to the Model Law (which the writer suggests would be far less satisfactory) but only after appropriate research. (Good news for arbitration law students?)

\section{Local standards annulments}

In the last offering in this section, Jan Paulsson, also of Paris, reverts like Mr Kaplan to an earlier theme with which he has become associated, namely the desirability in certain circumstances of enforcing awards notwithstanding LSAs ('local standards annulments'), as he has dubbed them. The freedom for a country to make 'whatever rules it wishes' on grounds to annul awards made within its jurisdiction can create problems, because art. V(1)(e) makes non-recognition or nonenforcement, possible on the basis that the award has been set aside by its 'home' court. This speaker has been a leading proponent of limiting exercise of this discretion to cases where the setting aside has been effected on criteria consonant with a 'contemporary international consensus'. There is a basis of achieving this result by applying art. VII instead of V(1)(e), as indeed was done in America in Chromalloy Aeroservices Inc v Arab Republic of Eqypt (1997) 22 YBCA 691, 1001 (a decision later criticised Professor van den Berg). However, it may be too radical a solution. A proposal for creating groups of 'approved' countries is rejected as unfortunate. Mr Paulsson's preferred solution is to hand, for art. V is discretionary, listing the only grounds on which enforcement or recognition may be refused. Judges can already apply that discretion by reference to international standards. Amendment or supplementation of the convention is thus not necessary though it may be helpful. It remains to be seen how many national courts will be converted to this way of thinking, skilful though the presentation is.

\section{THE JUDICIAL PANEL}

The fourth section is that likely to be of least immediate interest to the general reader. A panel of judges from Egypt, 
Canada, Thailand, USA and Argentina was asked to answer two questions. The first related to the use to be made of the decision of 'foreign' courts when dealing with a convention case and how that should be done. The second dealt with possible programmes to familiarise national judges with convention issues and how that might be done. As might be expected, the answers are varied and interesting.

\section{WAYS FORWARD}

To close the meeting, five speakers spoke on the theme 'The future: what needs to be done'. Dr Gerold Herrmann, Secretary to UNCITRAL gave a progress report on the joint UNCITRAL/IBA project to monitor the effectiveness of implementation of the convention. Professor Zawera, of Mexico City, made a plea for more information, technical assistance and training in relation to the convention, a role in which he thought UNCITRAL ideally placed to take a leading role, with an international association of 'arbitration judges' as another possibility.

Next came Professor van den Berg, not so much a founding father as the recording angel of the convention, who dealt with the need to promote as uniform an interpretation and application of the convention as possible - a matter distinct from proposals to remedy shortcomings in its text and structure. On the first, one could summarise it, a little frivolously, as the headmaster's report of 'Doing well, could possibly be doing better and, above all, must keep alert and avoid complacence or back-sliding'. As to reforms, he lists the concerns expressed; in addition to those dealt with in the third session of the day, he mentions the question of whether the convention provisions should be applied to enforcement of awards in the country of origin, waiver, grounds of refusal and enforcement procedures. On the latter he suggests that the UNCITRAL/IBA project could provide the basis for a model law on enforcement. Otherwise he believes most of the points could be achieved by judicial interpretation and expresses some reservations on the desirability of amending the convention by a protocol or supplemental convention. His suggested solution is a model law for enforcenent of awards effectively outside the Convention pursuant to its art. VII(i), a proposal he elaborates with reference, by way of example, to the laws of the Netherlands and France which have cut back the permissible grounds of refusal in art. V. (He also gently criticises laggards such as Switzerland and Germany). Professor Werner Melis, of Vienna, discusses the possible content of an additional convention ('NYC II' as we would doubtless come to know it). His paper largely builds upon and endorses the earlier specific proposal.

Mr Gavan Griffith, former Solicitor-General of Australia, winds up with a list of topics for a possible annex to the Model Law. It would cover arbitrability, the definition of an arbitration agreement, confidentiality, consolidation, the award of interest, costs, arbitral immunity and interim measures. Few could quarrel with his list, but it would be a formidable and ambitious aim to achieve.

\section{A SUMMATION}

Twenty-two speakers from more than fifteen countries under five distinguished chairmen - Ambassador Mozilu of Romania, Tang Houzhi of CIETAC, Haya Sheikh Al Khalifa of Bahrain, Judge Howard Holtzmann of America and Muchadeyi Masunda of Zimbabwe. What an exciting, if exhausting, day it must have been! The fashion to celebrate 40th anniversaries is relatively new, and it will indeed be fascinating to see what progress has been made when the more traditional 50th birthday comes along. Will it, one wonders, exude the satisfaction and enthusiasm this event clearly, and not unjustifiably, did? Perhaps we'll even have a lady 'lead' speaker too!

\section{Prof J E Adams}

Professor Emeritus at Queen Mary and Westfield College, University of London; Visiting Professor at City University.

\title{
The Coffin Memorial Lecture on the History of Ideas
}

\author{
Monday 3 April 2000, 6.00pm \\ Chancellor's Hall, Senate House, Malet Street, London WC1E 7HU \\ The Hon Justice Carsten Smith \\ President of the Norwegian Supreme Court \\ Judicial Review of Parliamentary Legislation: \\ Norway as a European Pioneer \\ Chair: The Rt Hon Lord Woolf \\ Master of the Rolls and Pro Chancellor of the University of London \\ Admission free and all are welcome. \\ Drinks and light refreshments will follow both lectures
}

For further information contact Belinda Crothers at the Institute of Advanced Legal Studies, Charles Clore House, 17 Russell Square, London, WC1B 5DR, on 02076371731 (e-mail: bcrother@sas.ac.uk). 